\title{
IPTEKS PELAPORAN PERSEDIAAN PADA PUPRD SULUT
}

\author{
Reyfando Bilgery Mangarey ${ }^{1}$, Gabriela Nikita Mose $^{2}$, Lintje Kalangi $^{3}$ \\ 1,2,3 Jurusan Akuntansi, Fakultas Ekonomi dan Bisnis, Universitas Sam Ratulangi, Kampus Unsrat, Manado, \\ 95115, Indonesia \\ E-mail :reybilgery@gmail.com
}

\begin{abstract}
Government Regulation No. 71 of 2010 concerning Government Accounting Standards in recording inventory can realize the performance performed by government agencies, especially in the presentation of inventory reporting. The purpose of this study was to determine the government accounting standard policies in reporting inventory at the Office of Public Works and Regional Spatial Planning of North Sulawesi Province according to Government Regulation Nomber. 71 of 2010 based on PSAP 05 concerning Inventory Accounting and the method used in this research is the service inventory reporting analysis method Public Works and Regional Spatial Planning of North Sulawesi Province with the technique of science and technology collecting inventory data and conducting analysis. The results of this study indicate that inventory reports at the Public Works Agency and Regional Spatial Planning of North Sulawesi Province are stated to be in accordance with government accounting standards.
\end{abstract}

Keywords: Policies, government regulations, Inventory Reporting

\section{PENDAHULUAN}

Salah satu cara untuk melihat sebuah keberhasilan dilembaga pemerintahan, selain tugas dan fungsi yang terlaksana dengan baik dan harus juga memperhatikan tata cara pengelolaan keuangannya, apabila keuangannya sudah terkelola dengan baik maka system yang berada didalamnya juga pasti akan melaksanakannya dengan baik. Dan sala satu cara mewujudkan tata kelola keuangannya yang baik harus sesuai dengan aturan yang berlaku instansi pemerintahan. Kementrian PUPR adalah suatu lembaga yang termasuk disektor pemerintahan tentunya dalam pembuatan laporan keuangannya harus menyesuaikan dengan standar yang berlaku disektor pemerintah, dan yang menjadi dasar acuan yaitu Standar Akuntansi Pemerintahan.

SAP mengatur semua isi pelaporan keuangan pemerintah secara merata, dan berdasarkan dengan PSAP Nomor 05 terdapat didalam lampiran PP. Nomor 71 Tahun 2010, terdapat dilampiran 1.06 untuk Standar Akuntansi Pemerintahan (SAP). Didalam pernyataan standar ini diterapkan dalam seluruh pelaporan keuangan dan persediaan yang bertujuan umum, standar ini juga yang diterapkan untuk semuan entitas yang berada disektor pemerintahan. Didalam pelaporan keuangan dikementrian PUPR khususnya Dinas PUPRD Sulut yang didalamnya menyangkut pelaporan persediaan contohnya barang konsumsi, asumsi, bahan untuk pemeliharaan, suku cadang, bahan baku, tanah/bangunan, dan persediaan untuk tujuan strategis. Dari pembahasan diatas sehingga penulis ingin membahas lebih lanjut mengenai persediaan.

\section{TINJAUAN PUSTAKA}

Standar Akuntansi Pemerintahan (SAP). Standar Akuntansi pemerintahan merupakan standar acuan instansi di lembaga pemerintahan dalam penyajian penyusunan LKPD dan juga LKPP. SAP juga suatu prinsip akuntansi yang diberlakukan dalam menyajikan dan penyusunan laporan keuangan pemerintah agar dapat menghasilkan laporan 
keuangan dengan kualitas yang baik, seperti yang telah di tentukan melalui Peraturan yang berlaku dalam Instansi pemerintah. Menurut Putu Istaguein Ryan P 2013-2014 SAP adalah suatu faktor penentu LKPD, oleh karena itu penerapan Standar Akuntansi Persediaan sangat diperlukan dalam menghasilkan transparansi LKPD yang berkualitas. Menurut Retnaningtyas Widuri dan Olga Yani Fransiska Singkali 2014 menyatakan bahwa SAP merupakan prinsip akuntansi untuk menyusun juga dalam menyajikan laporan keuangan dalam instansi pemerintah yang telah ditetapkan dalam PP Nomor. 24 Tahun 2005, sedangkan didalam PP Nomor. 24 Tahun 2005 Pasal 1 SAP yaitu prosedur manual atau terkomputerisasi dalan mengumpulkan data, pengiktisaran, mencatat data, dalam pelaporan posisi keuangan, dan juga dalam pelaporan operasi keuangan pemerintah. Ada tujuh laporan keuangan yang harus disiapkan oleh lembaga pemerintahan, yaitu : (1) LRA; (2) SAL; (3) LO; (4) perubahan ekuitas; (5) neraca; (6) arus kas; dan (7) catatan laporan keuangan.

Laporan Keuangan PUPRD. Laporan Keuangan merupakan suatu informasi yang sangat penting dan diperlukan dalam perusahaan atau bisnis untuk dapat mengukur dan menggambarkan kondisi dari hasil keuangan dalam perusahaan dengan jangka waktu tertentu, sedangkan dalam SAK proses dari laporan keuangan yang lengkap harus meliputi rugi laba, neraca, dan laporan posisi keuangan. Menurut Umi Riyanti (2011) Laporan keuangan adalah sumber informasi untuk pemerintah baik dalam mengambil kebijakan atau keputusan, juga dapat menjadi informasi bagi pihak selain pemerintah seperti investor, calon investor, bank, dan perusahaan. Dalam kepentingan para pengguna laporan keuangan sangatlah berbeda-beda, sesuai dengan keperluaannya masing-masing. Pada dasarnya laporan keuangan merupakan gambaran peistiwa transaksi yang telah terjadi. Dalam penyusunan laopran keuangan kementrian pekerjaan umum harus mengikuti prosedur peraturan Direktur Jendral Pembendaharaan tentang penyusunan laporan keuangan Negara, Kementrian, dan Lembaga yang terdapat dalam peraturan Nomor PER- 57 / PB/2013. Dalam UU Nomor. 17 Tahun 2003 yaitu Keuangan Negara dalam Pasal 36 terdapat di ayat 1 yaitu dalam pengukuran pembenaran pendapatan, yang harus diselesaikan paling lambat 5 tahun, Sehingga pemerintah menerbitkan kembali peraturan baru Nomor 71 tahun 2010. Tepatnya pada bulan Oktober tahun yang sama.

Persediaan. Menurut Farahmita( 2006) menjelaskan bahwa Persediaan adalah barang yang dimiliki untuk dipakai atau disimpan untuk dijual kembali dalam periode tertentu untuk tujuan kegiatan bisnis usaha, dan barang yang mendukung kelancaran perusahaan dan dipakai untuk membantu pelaksanaan kegiatan produksi bisnis perusahaan atau persediaan yang disimpan dengan maksud yang sama. Sedangkan didalam PSAP Nomor 05 persediaan adalah asset lancar dalam bentuk baranng setenga jadi atau barang jadi yang berguna mendukung kegiatan dalam pelaksanaan operasional pemerintah, atau barang yang akan dijual dalam suatu periode atau diserahkan dalam pelayanan masyarakat, sedangkan didalam perusahaan manufaktur persediaan terbagi atas tiga kategori yaitu; raw material, work in process, dan finished good. Menurut Kristin Petra Laikyer dalam Jurnal Riset Mahasiswa Persediaan dikelompokan sebagai barang-barang habis pakai contohnya, ATK dan tidak habis pakai seperti pipa dan barang bekas lainnya. Menurut Rizka Putri Rifai 2016 Persediaan dapat di laporkan dengan 2 metode yaitu:

1. Perpetual. Untuk metode perpetual, Metode ini dipakai untuk jenis-jenis persediaan yang berkaitan dengan kegiatan operasional di Satuan Kerja Perangkat Daerah dan diperlukan pengendalian yang kuat untuk pengelolaannya.

2. Periodik. Untuk periodik, akuntansi berfungsi tidak secara langsung ketika nilai persediaan terjadi pemakaian. Dalam metode ini perusahaan hanya dapat melihat jumlah barang atau persediaan pada akhir periode. Dengan melakukan stock opname maka Jumlah persediaan akhir periode akan diketahui. 


\section{METODE DAN TEKNIK PENERAPAN IPTEKS}

\subsection{Penerapan Metode Ipteks}

Penerapan metode ipteks yaitu menganalisis penerapan pelaporan persediaan Dinas PUPRD Sulawesi Utara sesuai dengan Standar akuntansi pemerintahan.

\subsection{Penerapan Teknik Ipteks}

Penerapan teknik ipteks yaitu mengumpulkan data laporan persediaan PUPRD Prov. Sulut dan melakukan analisis kenyesuaian sesuai dengan PSAP Nomor 5 mengenai persediaan.

\section{PEMBAHASAN}

\subsection{Gambaran Objek Penerapan Ipteks}

Dinas PUPRD Sulut adalah suatu lembaga pemerintahan yang bertempat di JL. Tikala Ares Nomor. 80 (Tikala), manado, Sulawesi utara merupakan perangkat daerah untuk melaksanakan tugas pemerintahan yang mambidangi urusan pekerjaan umum dan penataan ruang daerah, yang terutama menangani pelayanan dibidang infrastruktur terlebih dalam pelaksanaan konstruksi didaerah yang khususnya Sulawesi Utara. Departemen Pemukiman dan Pembangunan Wilayah dari tahun 1999 sampai tahun 2000 dan sempat di rubah menjadi Departemen Pemukiman dan Prasarana Wilayah dari tahun 2000 sampai dengan tahun 2004, dan yang sekarang dirubah kembali menjadi Kementrian Pekerjaan Umum dan Perumahan Rakyat sejak tahun 2004 sampai dengan sekarang, PUPR bertugas untuk Pemerintah Indonesia yang membidangi pekerjaan umum dan perumahan rakyat. Kementerian Pekerjaan Umum dan Perumahan Rakyat ini berada di bawah pimpinan tanggung jawab Presiden Rpublik Indonesia. Yang dipimpin langsung oleh Menteri Pekerjaan Umum dan Perumahan Rakyat sejak tanggal 27 Oktober 2014 yang dijabati oleh Basuki Hadimuljono. Dan untuk PUPRD provinsi sulawesi utara yang sekarang ini dipimpin oleh Steve. H. A. Keppel, St, Msi.

\subsection{Pembahasan}

Prosedur penambahan persediaan pada PUPRD. Persediaan termasuk aset lancar berupa perlengkapan-perlengkapan yang diharapkan bisa mendorong kegiatan operasional dari pemerintah, yang juga dapat dijual dalam rangka pelayanan kepada masyarakat. Untuk kementrian pekerjaan umum pencatatan persediaan disusun pada : harga terakhir pembelian, jika didapat dari pembelian, harga standar jika didapat dari hasil produksi, dan harga wajar apabila didapat dari cara lain seperti donasi dan sebagainya. Dinas PU prov sulut merupakan cabang dari kementrian pekerjaan umum, dan tentunya dari segi pendanaan harus melalui penganggaran dari pusat kementrian pekerjaan umum perumahan rakyat (PUPR). Dengan keterkaitan pada judul penelitian saat ini tentang persediaan. Di dinas PU provinsi sulawesi utara yang didalamnya terdapat empat bidang yang harus membuat pengajuan tentang persediaan, lalu akan disetujui oleh kuasa pengguna barang. Untuk laporan persediaan dinas PUPRD SULUT ada beberapa bagian yang harus dibuat yaitu:

1. Daftar transaksi persediaan, didalamnya berisi barang-barang yang nantinya akan digunakan untuk keperluan bidang, dan kegiatan operasional sehari-hari bidang tersebut.

2. Laporan transaksi barang persediaan yang berisi barang-barang berupa, barang konsumsi, dan bahan untuk pemeliharaan.

3. Laporan posisi persediaan di neraca berisi dua bagian yaitu barang konsumsi dan bahan untuk pemeliharaan.

Setelah bagian-bagian tersebut sudah selesai di buat maka diteruskan kepada satuan kerja kuasa pengguna barang dan apabila sudah sesuai maka akan disetujui. Hal-hal tersebut yang menjadi ukuran untuk pelaporan persediaan dinas PUPRD Sulut.

Persediaan menurut PSAP No. 5. Dalam PSAP definisi persediaan yaitu barang atau perlengkapan yang termasuk di dalam aset lancar yang nantinya pada waktu tertentu 
akan di jual dalam mundukung dan membantu kegiatan bisnis perusahaan maupun diberikan untuk pelayanan dalam masyarakat. Persediaan termasuk aset lancar di dalamnya:

1. Perlengkapan atau barang yang digunakan untuk membantu pelaksanaan operasional.

2. Barang-barang untuk membantu produksi.

3. Barang dalam proses untuk nantinya di jual.

4. Perlengkapan dan barang yang disimpan yang akan di jual pada tempo waktu tertentu diberi untuk melayani masyarakat.

Untuk laporan keuangan termasuk persediaan dalam PSAP No. 5 harus mengikuti kebijakan akuntansi untuk persediaan.

Analisis kesesuaian persediaan dinas pekerjaan umum dengan PSAP No. 5. Berdasarkan prosedur diatas dan regulasi PSAP No. 5 dapat dilihat bahwa pelaporan dinas pekerjaan umum mengikuti PSAP No. 5 contohnya yaitu :

1. Pendanaan. Pendanaan Dinas PUPRD langsung dari pusat yaitu Kementrian Pekerjaan Umum Perumahan Rakyat sesuai dengan peraturan pemerintah Nomor 21 tahun 2004.

2. Pelaporan persediaan. Berdasarkan laporan posisi persediaan di neraca kementrian Pekerjaan Umum melaporkan sesuai dengan PSAP No. 5, yaitu seperti: (a) Barang konsumsi; dan (b) Bahan untuk pemeliharaan.

3. Penggunaan. Persediaan yang dimiliki oleh Dinas PUPRD diginakan untuk kegiatan operasional pemerintah sesuai dengan PSAP No. 5 yaitu standar yang berlaku untuk instansi pemerintah.

\section{KESIMPULAN DAN SARAN}

\subsection{Kesimpulan}

Dinas Pekerjaan Umum dan Penataan Ruang Daerah (PUPRD) yang termasuk dilembaga atau instansi pemerintah yang menangani pelayanan dibidang infrastruktur terlebih dalam pelaksanaan konstruksi. Dalam pelaporan keuangan harus menyesuaikan dengan aturan yang berlaku dipemerintahan, terdapat di PP. No 71 Tahun 2010 yaitu Standar Akuntansi Pemerintahan. Persediaan yaitu aset lancar berupa stock perlengkapan, barang yang akan membantu pelaksanaan aktivitas operasional sektor pemerintah, dan stok persediaan yang disimpan untuk dijual dalam periode tertentu untuk diberi kepada masyarakat. Dalam penelitian ini bertujuan untuk menguji Persediaan pada Dinas PUPRD Prov Sulut apakah sudah sama/sesuai dengan PSAP. Penelitian ini membuktikan bahwa pelaporan persediaan sudah sesuai dengan standar yang berlaku, dibuktikan dengan beberapa hal dalam pembahasan di atas yaitu, 1 pendanaan ,2 pelaporan persediaan, dan 3 penggunaan seperti yang telah dijelaskan dalam PSAP No 5 dan didalam peraturan pemerintah Nomor 21 Tahun 2004.

\subsection{Saran}

Saran untuk Dinas (PUPRD) Provinsi Sulut utara agar untuk kedepannya lebih meningkatkan cara pelaporan khususnya persediaan dengan menyesuaikannya dengan standar yang berlaku dengan persediaan tersebut

\section{DAFTAR PUSTAKA}

Laporan persediaan Dinas pekerjaan Umum dan Penataan Ruang Daerah Provinsi sulawesi utara periode 2017

Peraturan pemerintah Republik Indonesia Nomor 71 Tahun 2010 tentang Standar Akuntansi Pemerintahan

Laporan Kinerja Kementrian Pekerjaan Umum dan Perumahan Rakyat tahun 2016

Laporan Anggaran Kementrian Pekerjaan Umum Tahun Anggaran 2014 
Peraturan Mentri keuangan Pepublik Indonesia Nomor 233/PMK.05/2011. Perubahan Atas Peraturan Mentri Keuangan Nomor 171/PMK.05/2007 Tentang Sistem Akuntansi dan Pelaporan Keuangan Pusat

Rizka Putri Rifai, Jantje J. Tinangon, 2016. Evaluasi Kebijakan Akuntansi Dalam Pengukuran Persediaan Sesuai Pernyataan Standar Akuntansi Pemerintahan Nomor 05 Tentang Akuntansi Persediaan Pada Dinas Pekerjaan Umum Sulawesi Utara. Jurnal EMBA, 5(1), 11-19

Putu Istaguein Ryan Parartha, 2014. Pengaruh Penerapan Standar Akuntansi Pemerintahan (SAP) Terhadap Transparansi Laporan Keuangan Pemerintah Daerah (LKPD). Undergraduate Thesis, UPN "Veteran" Jawa Timur

Ria Irawati, 2016. Analisis Penerapan Akuntansi Persediaan dan Akuntansi Aset Tetap Pada Satuan Kerja Perangkat Daerah di Kabupaten Sopeng, Studi Kasus pada Badan Kepegawaian dan Diklat Daerah. S1 thesis, Universitas Negeri Makassar

Olga Yani Fransiska Singkali dan Retnaningtyas Widuri, 2014. Penerapan Standar Akuntansi Pemerintahan Pada Dinas Pendapatan dan Pengelolaan Aset Daerah (DPPKAD) Kabupaten Toraja Utara. Tax and Accounting Reviuw, 4(2), 1-15

Yesi, Kardinal, 2014. Analisis Perencanaan dan pengendalian persediaan barang jadi pada CV, Tedmon Fibre Glass. Skripsi, STIE MDP 1-6

Umi Riyanti, 2011. Analisis Laporan Keuangan Pemerintah Pada Dinas Bina Marga dan Sumber Daya Air Kabupaten Pelalawan. Skripsi thesis, Universitas Islam Negeri Sultan Sarif Kasim Riau

Estephany Gloria Sipetu, 2016. Analisis Pencatatan dan Pelaporan Belanja Modal Pada Direktorat Jendral Cipta Karya Dinas Pekerjaan Umum Provinsi Sulawesi Utara. Jurnal Berkala Ilmiah Efisiensi, 16(1), 441-448

Kristin Petra Laikyer, 2016. Analisis Kebijakan Akuntansi Yang Digunakan Dalam Pengukuran Persediaan Sesusi Pernyataan Standar Akuntansi Pemerintahan Nomor 05 (PSAP 05) Tentang Akuntansi Persediaan. Jurnal Riset Mahasiswa Akuntansi,4(2), 115 